\title{
Humanitarian evidence and discourse summary No.22
}

Luke Kelly

University of Manchester

January 2022

Monthly Humanitarian Evidence and Discourse Summaries aim to signpost FCDO and other UK government departments to the latest relevant evidence and discourse on humanitarian action. It is structured around three themes:

- Protect: Protect civilians, IDPs, refugees, marginalised groups including women and girls, and humanitarian access.

- Prioritise: Prioritise effective humanitarian assistance to people in greatest need

- Prevent: Prevent and anticipate future shocks and rebuild resilience in protracted and recurring crises

Further detail on methodology, scope and resource hubs at the end. Click on the following hyperlinks to bring you down to the relevant literature.

\section{Protect}

\begin{tabular}{|c|c|c|c|c|}
\hline $\begin{array}{l}\text { Publication } \\
\text { date }\end{array}$ & Title/URL & $\begin{array}{l}\text { Publication type (evidence, } \\
\text { discourse or policy/guidance) }\end{array}$ & Summary & $\begin{array}{l}\text { HoP } \\
\text { Top } \\
\text { reads }\end{array}$ \\
\hline $\begin{array}{l}\text { December } \\
2021\end{array}$ & $\begin{array}{l}\text { Being the } \\
\text { difference: A } \\
\text { primer for states } \\
\text { wishing to prevent } \\
\text { atrocity crimes in } \\
\text { the mid-twenty- } \\
\text { first century }\end{array}$ & $\begin{array}{l}\text { Fred Carver and Kate } \\
\text { Ferguson; Protection } \\
\text { Approaches } \\
\text { Evidence }\end{array}$ & $\begin{array}{l}\text { Argues that states and civil society } \\
\text { should adopt the responsibility to } \\
\text { protect (R2P) doctrine more. It } \\
\text { identifies a 'pathology of violence' } \\
\text { at the root of atrocities: identify- } \\
\text { based grievances; organised } \\
\text { criminal conspiracy; and a lack of } \\
\text { checks on power. Both stable and } \\
\text { fragile countries are vulnerable to } \\
\text { atrocities. They argue that a focus } \\
\text { on human rights can help address } \\
\text { the issue. Outlines these drivers } \\
\text { and how the existing R2P } \\
\text { architecture could be devolved to } \\
\text { states through locally-led and } \\
\text { horizontal approaches. }\end{array}$ & \\
\hline $\begin{array}{l}\text { November } \\
2021\end{array}$ & $\begin{array}{l}\text { Why Not Local? } \\
\text { Gender-based } \\
\text { Violence, } \\
\text { Women's Rights } \\
\text { Organisations, } \\
\text { and the Missed } \\
\text { Opportunity of } \\
\text { COVID-19 }\end{array}$ & $\begin{array}{l}\text { Marcy Hersch; International } \\
\text { Rescue Committee } \\
\text { Evidence }\end{array}$ & $\begin{array}{l}\text { Outlines the risks of gender-based } \\
\text { violence (GBV) intensified by } \\
\text { Covid-19, and shows how local } \\
\text { women's rights organisations have } \\
\text { taken on more responsibility during } \\
\text { the pandemic but still face barriers } \\
\text { to funding from the international } \\
\text { system. }\end{array}$ & \\
\hline
\end{tabular}




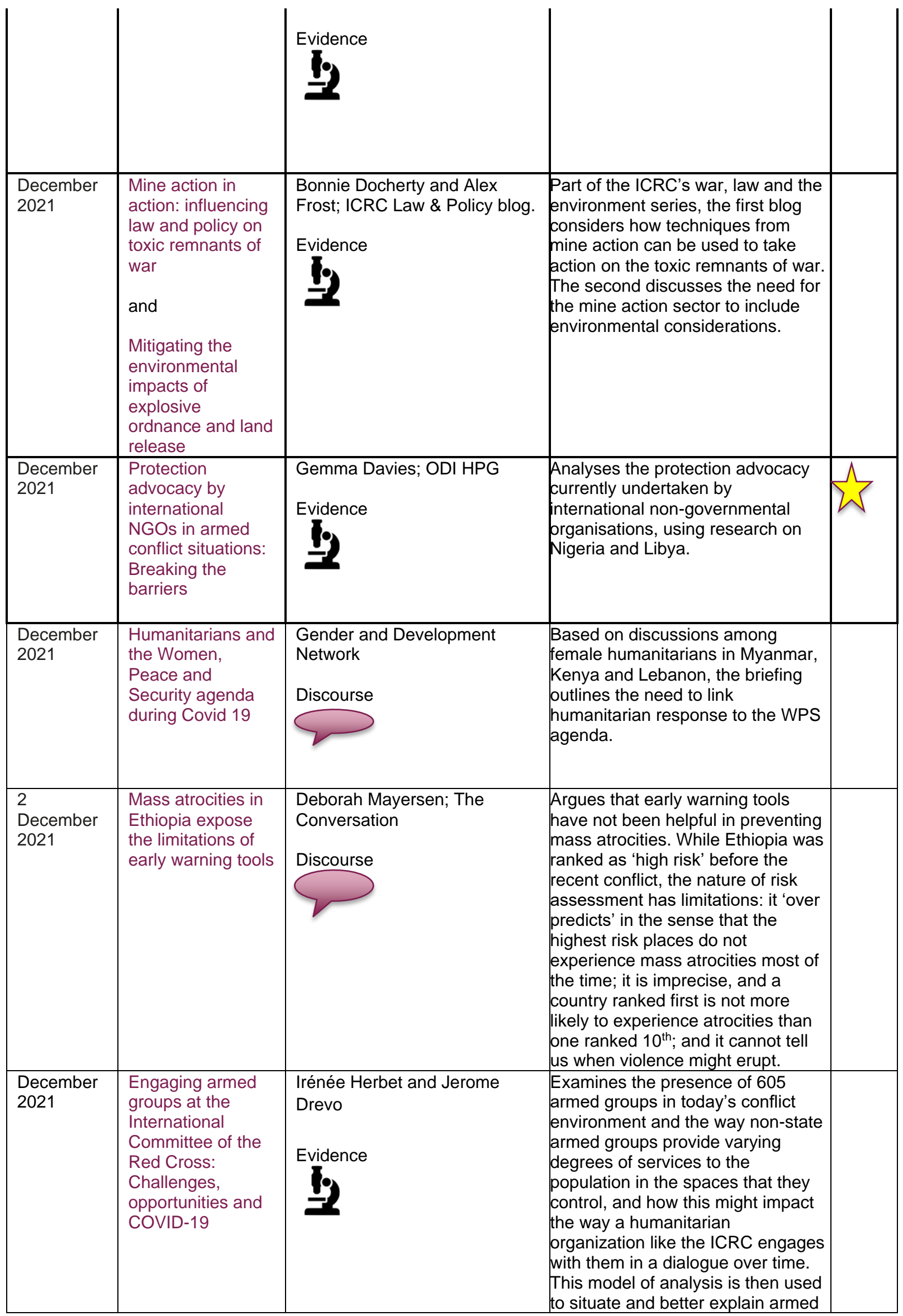




\begin{tabular}{|l|l|l|l|l|}
\hline & & & $\begin{array}{l}\text { groups' positions on the COVID } \\
\text { crisis. }\end{array}$ & \\
& & & & \\
\hline
\end{tabular}

\section{Prioritise}

\begin{tabular}{|c|c|c|c|c|}
\hline $\begin{array}{l}\text { Publication } \\
\text { date }\end{array}$ & Title/URL & $\begin{array}{l}\text { Publication type (evidence, } \\
\text { discourse or policy/guidance) }\end{array}$ & Summary & $\begin{array}{l}\text { Top } \\
\text { reads } \\
\end{array}$ \\
\hline $\begin{array}{l}3 \\
\text { December } \\
2021\end{array}$ & $\begin{array}{l}\text { Accountability in } \\
\text { Humanitarian } \\
\text { Action }\end{array}$ & $\begin{array}{l}\text { Dorothea Hilhorst et al., } \\
\text { Refugee Survey Quarterly } \\
\text { Evidence }\end{array}$ & $\begin{array}{l}\text { Surveys the history and current trends } \\
\text { in humanitarian accountability. It } \\
\text { includes case studies of Myanmar, } \\
\text { Afghanistan and Sierra Leone, tracing } \\
\text { upward, sideways and downward } \\
\text { accountability, as well as formal and } \\
\text { informal methods. Findings include that } \\
\text { accountability is talked about by all } \\
\text { actors, but progress is uneven. A lack } \\
\text { of harmonisation in reporting to donors, } \\
\text { uneven progress on accountability to } \\
\text { affected populations, and difference } \\
\text { between the UN and international } \\
\text { NGOs on the one hand, and national } \\
\text { NGOs on the other. }\end{array}$ & \\
\hline $\begin{array}{l}9 \\
\text { December } \\
2021\end{array}$ & $\begin{array}{l}\text { Toolbox - Linking } \\
\text { Humanitarian } \\
\text { CVA and Social } \\
\text { Protection }\end{array}$ & $\begin{array}{l}\text { Gabrielle Smith, CALP } \\
\text { Policy/guidance }\end{array}$ & $\begin{array}{l}\text { A spreadsheet summarising over } 150 \\
\text { resources on linking cash assistance } \\
\text { and social protection. Including } \\
\text { feasibility assessment, programme } \\
\text { design, country-specific templates, and } \\
\text { training. }\end{array}$ & 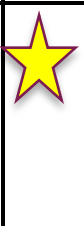 \\
\hline $\begin{array}{l}\text { December } \\
2021\end{array}$ & $\begin{array}{l}\text { The Covid-19 } \\
\text { pandemic: global } \\
\text { dimensions, local } \\
\text { responses }\end{array}$ & $\begin{array}{l}\text { Disasters; special issue } \\
\text { Evidence }\end{array}$ & $\begin{array}{l}\text { Special issue on the effects of covid- } \\
19 \text {, including on health governance, } \\
\text { protective policies for the vulnerable, } \\
\text { cash assistance and urban refugees, } \\
\text { among others. }\end{array}$ & \\
\hline $\begin{array}{l}3 \\
\text { December } \\
2021\end{array}$ & $\begin{array}{l}\text { Humanitarian } \\
\text { action in 2021: } \\
\text { tensions, trade- } \\
\text { offs and dilemmas }\end{array}$ & $\begin{array}{l}\text { Sorcha O'Callaghan; Martin } \\
\text { Griffiths; Orzala Nemat } \\
\text { Discourse }\end{array}$ & $\begin{array}{l}\text { Recording of discussion on the politics, } \\
\text { principles and pragmatism of } \\
\text { humanitarian action in the face of } \\
\text { reduced access and threats to } \\
\text { rights and protection. }\end{array}$ & \\
\hline $\begin{array}{l}17 \\
\text { December } \\
2021\end{array}$ & $\begin{array}{l}\text { Localisation Re- } \\
\text { imagined: } \\
\text { Fertilising the soil } \\
\text { of state-led } \\
\text { solutions }\end{array}$ & $\begin{array}{l}\text { Arbie Baguois; ALNAP } \\
\text { Discourse }\end{array}$ & $\begin{array}{l}\text { The second part of five blogs on } \\
\text { localisation focuses on the ways in } \\
\text { which humanitarian actors working with } \\
\text { national governments can be part of } \\
\text { localisation. }\end{array}$ & \\
\hline $\begin{array}{l}6 \\
\text { December } \\
2021\end{array}$ & $\begin{array}{l}\text { Stress Testing } \\
\text { Social Protection } \\
- \text { A rapid } \\
\text { appraisal of the } \\
\text { adaptability of } \\
\text { social protection } \\
\text { systems and their }\end{array}$ & $\begin{array}{l}\text { Christian Bodewig et al. } \\
\text { Policy/guidance }\end{array}$ & $\begin{array}{l}\text { Putlines how a 'stress test' can rapidly } \\
\text { measure a country's ability to adapt or } \\
\text { scale its social protection system in } \\
\text { times of crisis. Provides a stress test } \\
\text { tool, and guidance on how to adapt it. }\end{array}$ & \\
\hline
\end{tabular}




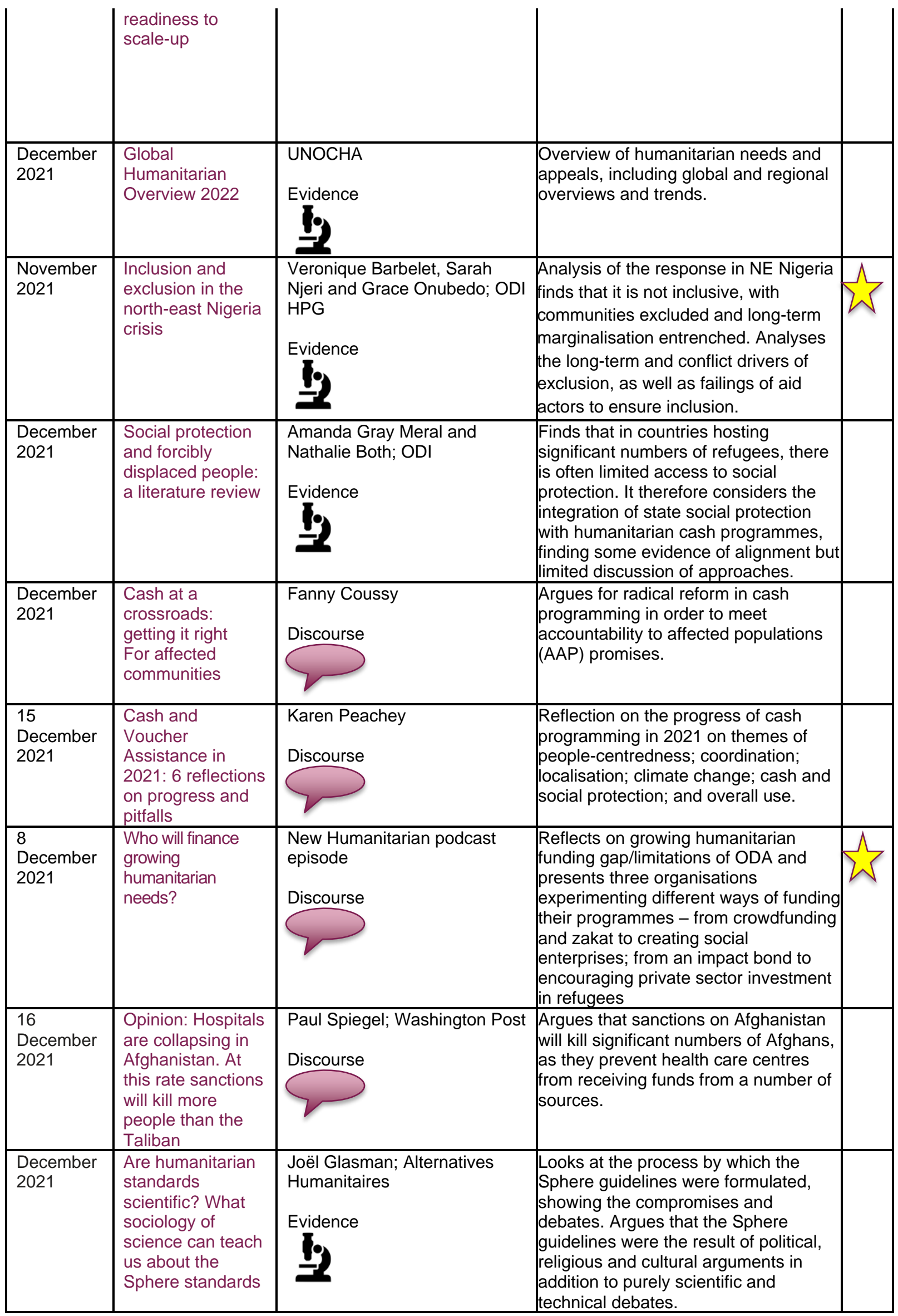




\begin{tabular}{|c|c|c|c|c|}
\hline $\begin{array}{l}\text { Publication } \\
\text { date }\end{array}$ & Title/URL & $\begin{array}{l}\text { Author(s)/Publication/Publicati } \\
\text { on type (evidence, discourse } \\
\text { or policy/guidance) }\end{array}$ & Summary & $\begin{array}{l}\text { Top } \\
\text { reads }\end{array}$ \\
\hline $\begin{array}{l}\text { December } \\
2021\end{array}$ & $\begin{array}{l}\text { Annual Report } \\
\text { 2020-2021 }\end{array}$ & $\begin{array}{l}\text { Refugee Studies Centre } \\
\text { Evidence }\end{array}$ & $\begin{array}{l}\text { A summary of the RSC's recent and } \\
\text { ongoing research projects. }\end{array}$ & \\
\hline $\begin{array}{l}\text { December } \\
2021\end{array}$ & $\begin{array}{l}\text { Climate change } \\
\text { and humanitarian } \\
\text { action }\end{array}$ & $\begin{array}{l}\text { Paul Knox-Clarke; PREPARE } \\
\text { Initiative. } \\
\text { Evidence } \\
\text { (0) }\end{array}$ & $\begin{array}{l}\text { Analysis of the effects of climate } \\
\text { change on humanitarian needs, and } \\
\text { the state of readiness of the } \\
\text { humanitarian system and national } \\
\text { disaster management, including } \\
\text { potential changes. }\end{array}$ & \\
\hline $\begin{array}{l}\text { December } \\
2021\end{array}$ & $\begin{array}{l}\text { How can we } \\
\text { address future } \\
\text { health threats? }\end{array}$ & $\begin{array}{l}\text { Adam Strobeyko and } \\
\text { Tammam Aloudat; Graduate } \\
\text { Institute Geneva } \\
\text { Discourse }\end{array}$ & $\begin{array}{l}\text { Argues that international disaster laws } \\
\text { 'can offer a lens through which the } \\
\text { negotiations for and decisions on a } \\
\text { pandemic treaty can be examined'. }\end{array}$ & \\
\hline $\begin{array}{l}\text { November } \\
2021\end{array}$ & $\begin{array}{l}\text { Livelihood } \\
\text { Components of } \\
\text { Durable Solutions } \\
\text { for IDPs }\end{array}$ & $\begin{array}{l}\text { Abdirahman Ahmed } \\
\text { Muhumed, Elizabeth Stites, } \\
\text { Elizabeth Alexion, Delia Burns; } \\
\text { Feinstein International Center } \\
\text { Evidence }\end{array}$ & $\begin{array}{l}\text { Examines durable solutions for IDPs in } \\
\text { Ethiopia's Somali region: resettlement, } \\
\text { relocation and local integration. } \\
\text { Includes analysis of livelihoods, } \\
\text { challenges, and host-IDP relations. }\end{array}$ & \\
\hline $\begin{array}{l}\text { December } \\
2021\end{array}$ & $\begin{array}{l}\text { The Gender } \\
\text { Dimensions of } \\
\text { Forced } \\
\text { Displacement: } \\
\text { Findings from } \\
\text { New Empirical } \\
\text { Analysis }\end{array}$ & $\begin{array}{l}\text { Joint Data Center on Forced } \\
\text { Displacement } \\
\text { Evidence }\end{array}$ & $\begin{array}{l}\text { Includes both a literature review on the } \\
\text { gendered dimensions of forced } \\
\text { displacement, and findings from recent } \\
\text { World Bank research. Covers poverty, } \\
\text { livelihoods, gender-based violence, } \\
\text { and gender norms. }\end{array}$ & \\
\hline $\begin{array}{l}\text { December } \\
2021\end{array}$ & $\begin{array}{l}\text { Comparative } \\
\text { Reintegration } \\
\text { Outcomes } \\
\text { between Forced } \\
\text { and Voluntary } \\
\text { Return and } \\
\text { Through a } \\
\text { Gender } \\
\text { Perspective }\end{array}$ & $\begin{array}{l}\text { IOM } \\
\text { Evidence } \\
\text { (0) }\end{array}$ & $\begin{array}{l}\text { Report on the outcomes of returnees, } \\
\text { considering how demographic factors, } \\
\text { whether return was forced or } \\
\text { voluntary, gender, and forms of } \\
\text { assistance affect outcomes. Based on } \\
\text { research on Afghanistan, Bangladesh, } \\
\text { El Salvador, the Gambia, Nigeria and } \\
\text { Somalia. }\end{array}$ & \\
\hline
\end{tabular}




\begin{tabular}{|c|c|c|c|}
\hline $\begin{array}{l}15 \\
\text { December } \\
2021\end{array}$ & $\begin{array}{l}2021 \text { Internal } \\
\text { Displacement } \\
\text { Index report }\end{array}$ & $\begin{array}{l}\text { IDMC } \\
\text { Evidence }\end{array}$ & $\begin{array}{l}\text { Country-by-country index of internal } \\
\text { displacement for } 2021 \text {. }\end{array}$ \\
\hline $\begin{array}{l}\text { December } \\
2021\end{array}$ & $\begin{array}{l}\text { From Insecurity } \\
\text { to Health Service } \\
\text { Delivery: } \\
\text { Pathways and } \\
\text { System } \\
\text { Response } \\
\text { Strategies in the } \\
\text { Eastern } \\
\text { Democratic } \\
\text { Republic of the } \\
\text { Congo }\end{array}$ & $\begin{array}{l}\text { Chiara Altare et al.; Global } \\
\text { Health: Science and Practice } \\
\text { Evidence }\end{array}$ & $\begin{array}{l}\text { Analysis of the pathways by which } \\
\text { insecurity affects healthcare delivery in } \\
\text { the DRC, and adaptation strategies. }\end{array}$ \\
\hline
\end{tabular}

\section{Resource Hubs}

\begin{tabular}{|c|c|c|}
\hline Title/URL & Author/Organisation & Summary \\
\hline $\begin{array}{l}\text { Covid-19: tracking local } \\
\text { humanitarian action and } \\
\text { complementary partnerships }\end{array}$ & $\begin{array}{l}\text { Overseas Development } \\
\text { Institute, Humanitarian Policy } \\
\text { Group }\end{array}$ & $\begin{array}{l}\text { Map of complementary partnerships } \\
\text { and local humanitarian action across } \\
\text { the globe. }\end{array}$ \\
\hline $\begin{array}{l}\text { Social protection responses to } \\
\text { compounding risks: } \\
\text { Lessons from Covid-19 and } \\
\text { climate-related disasters }\end{array}$ & $\begin{array}{l}\text { Red Cross and Red Crescent } \\
\text { Climate Centre }\end{array}$ & $\begin{array}{l}\text { A data dashboard of social protection } \\
\text { responses to covid-19, at the national } \\
\text { and international level. }\end{array}$ \\
\hline $\begin{array}{l}\text { COVID-19 Data Explorer: } \\
\text { Global Humanitarian } \\
\text { Operations }\end{array}$ & $\begin{array}{l}\text { Humanitarian Data Exchange } \\
\text { (HDX) }\end{array}$ & $\begin{array}{l}\text { World map of covid cases and various } \\
\text { vulnerability and socio-economic risk } \\
\text { factors (including vaccine rollout, food } \\
\text { security, school closures, CERF } \\
\text { allocations etc.). }\end{array}$ \\
\hline $\begin{array}{l}\text { Covid-19 and Humanitarian } \\
\text { Crises }\end{array}$ & $\begin{array}{l}\text { Johns Hopkins Center for } \\
\text { Humanitarian Health, } \\
\text { Health in Humanitarian Crises } \\
\text { Centre, London School of } \\
\text { Hygiene and Tropical Medicine } \\
\text { and Geneva Centre of } \\
\text { Humanitarian Studies, The } \\
\text { Graduate Institute of } \\
\text { International and Development } \\
\text { Studies and the University of } \\
\text { Geneva }\end{array}$ & $\begin{array}{l}\text { Website for the exchange of field- } \\
\text { pased COVID-19 programme } \\
\text { adaptations and innovations. }\end{array}$ \\
\hline $\begin{array}{l}\text { Covid-19 Mobility Impact } \\
\text { Reports }\end{array}$ & UN IOM & $\begin{array}{l}\text { Frequently updated reports on } \\
\text { migration restrictions. }\end{array}$ \\
\hline $\begin{array}{l}\text { IDMC Internal Displacement } \\
\text { Updates }\end{array}$ & $\begin{array}{l}\text { Internal displacement } \\
\text { monitoring centre }\end{array}$ & Global data on internal displacement \\
\hline ACAPS Crisis in Sight & ACAPS & $\begin{array}{l}\text { Global overview of crisis, including } \\
\text { covid and conflict; as well as access } \\
\text { constraints. }\end{array}$ \\
\hline
\end{tabular}




\begin{tabular}{|c|c|c|}
\hline $\begin{array}{l}\text { CVA and COVID-19: } \\
\text { resources, guidance, events } \\
\text { and questions }\end{array}$ & CaLP & $\begin{array}{l}\text { Guidance and resources on covid and } \\
\text { cash transfers }\end{array}$ \\
\hline $\begin{array}{l}\text { IASC: COVID-19 Outbreak } \\
\text { Readiness and Response } \\
\text { guidance }\end{array}$ & $\begin{array}{l}\text { Inter-Agency Standing } \\
\text { Committee }\end{array}$ & $\begin{array}{l}\text { ASC principles and protocols adapted } \\
\text { to covid-19 }\end{array}$ \\
\hline $\begin{array}{l}\text { OCHA } \\
\text { COVID19 Resource Material }\end{array}$ & $\begin{array}{l}\text { Office for the Coordination of } \\
\text { Humanitarian Affairs }\end{array}$ & $\begin{array}{l}\text { A wide range of guidance and } \\
\text { resources from WHO, IASC, the EU, } \\
\text { IFRF and others, as well as country- } \\
\text { specific information. }\end{array}$ \\
\hline $\begin{array}{l}\text { Humanitarian Data Exchange: } \\
\text { COVID-19 Pandemic in } \\
\text { Locations with a Humanitarian } \\
\text { Response }\end{array}$ & $\begin{array}{l}\text { Humanitarian Data Exchange } \\
\text { (HDX) }\end{array}$ & $\begin{array}{l}\text { Global data on infections and deaths; } \\
\text { a list of data sets on cases and } \\
\text { prevention/mitigation measures. }\end{array}$ \\
\hline $\begin{array}{l}\text { Humanitarian Data Exchange: } \\
\text { Government Measures } \\
\text { Dataset }\end{array}$ & $\begin{array}{l}\text { Humanitarian Data Exchange } \\
\text { (HDX) }\end{array}$ & $\begin{array}{l}\text { Global data on government covid-19 } \\
\text { measures under } 5 \text { categories: Social } \\
\text { distancing; Movement restrictions; } \\
\text { Public health measures; Social and } \\
\text { economic measures; Lockdowns. }\end{array}$ \\
\hline $\begin{array}{l}\text { IEG Lesson Library: } \\
\text { Evaluative Resources and } \\
\text { Evidence to inform the } \\
\text { COVID-19 Response }\end{array}$ & $\begin{array}{l}\text { World Bank Independent } \\
\text { Evaluation Group }\end{array}$ & $\begin{array}{l}\text { A library of Evaluative Resources and } \\
\text { Evidence to inform the COVID-19 } \\
\text { Response }\end{array}$ \\
\hline $\begin{array}{l}\text { Relief Web: regional topic } \\
\text { pages for Covid-19 } \\
\text { and global topic pages }\end{array}$ & Relief Web & $\begin{array}{l}\text { Regional and global reports and } \\
\text { resources on humanitarian needs and } \\
\text { response. }\end{array}$ \\
\hline $\begin{array}{l}\text { IASC Accountability and } \\
\text { Inclusion Resources Portal }\end{array}$ & $\begin{array}{l}\text { Inter-Agency Standing } \\
\text { Committee }\end{array}$ & $\begin{array}{l}\text { A library of resources on accountability } \\
\text { and inclusion. }\end{array}$ \\
\hline $\begin{array}{l}\text { Attacked and Threatened: } \\
\text { Health care targeted in conflict } \\
\text { and COVID-19 }\end{array}$ & Insecurity Insight & $\begin{array}{l}\text { Map of violence and threats against } \\
\text { health care across the world. }\end{array}$ \\
\hline Conflict and Health & Conflict and Health & $\begin{array}{l}\text { Open-access journal on the health } \\
\text { mpacts of conflict. }\end{array}$ \\
\hline $\begin{array}{l}\text { International Journal of } \\
\text { Disaster Risk Reduction }\end{array}$ & $\begin{array}{l}\text { International Journal of } \\
\text { Disaster Risk Reduction }\end{array}$ & An interdisciplinary journal of DRR. \\
\hline Journal of Refugee Studies & Journal of Refugee Studies & $\begin{array}{l}\text { Research on forced migration and } \\
\text { responses to it. }\end{array}$ \\
\hline Disasters & Disasters & $\begin{array}{l}\text { Focuses on disaster management and } \\
\text { policy from academic and field } \\
\text { perspectives. }\end{array}$ \\
\hline $\begin{array}{l}\text { International Review of the } \\
\text { Red Cross }\end{array}$ & $\begin{array}{l}\text { International Review of the } \\
\text { Red Cross }\end{array}$ & $\begin{array}{l}\text { Journal focusing on international } \\
\text { humanitarian law, policy and action in } \\
\text { situations of conflict. }\end{array}$ \\
\hline
\end{tabular}

\section{Methodology:}

Given the wide range of topics covered, this monthly summary includes guidelines, blogs, news articles, dashboards, data, and editorials, in addition to policy and academic literature. Resources are selected based on their relevance to the themes of protect, prioritise and prevent. Entries are categorised as evidence (academic peer-reviewed articles or reports that have gone through a quality assurance process); discourse (opinion and 
discussion of key issues in the humanitarian sector); and policies and guidelines (newly published policies and guidelines on humanitarian response). The sources included are found through searches of academic literature, humanitarian think tanks, resource hubs and NGO websites. The searches are restricted to articles published in the previous month, in English. This is complemented by email recommendations from FCDO advisors and leading experts. It is the result of 1 day of work per month and is not intended to be a comprehensive summary of available evidence on humanitarian action but aims to make original documents easily accessible to decisionmakers. This is trial and error approach, which will be refined and changed over the coming weeks. If you have literature to include in the weekly summary, please email - luke.kelly@manchester.ac.uk.

\section{About this report:}

The monthly Humanitarian Evidence Summaries are not intended to replace professional advice and the researcher or the $\mathrm{K} 4 \mathrm{D}$ consortium cannot be held responsible for any decisions made on the basis of the summaries alone.

K4D services are provided by a consortium of leading organisations working in international development, led by the Institute of Development Studies (IDS), with Education Development Trust, Itad, University of Leeds Nuffield Centre for International Health and Development, Liverpool School of Tropical Medicine (LSTM), University of Birmingham International Development Department (IDD) and the University of Manchester Humanitarian and Conflict Response Institute (HCRI).

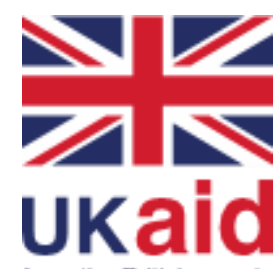

from the British people

This evidence summary was prepared for the UK Government's Foreign, Commonwealth and Development Office (FCDO) and its partners in support of pro-poor programmes. It is licensed for non-commercial purposes only. K4D cannot be held responsible for errors, omissions or any consequences arising from the use of information contained in this health evidence summary. Any views and opinions expressed do not necessarily reflect those of FCDO, K4D or any other contributing organisation.

(C) FCDO - Crown copyright 2021.

\section{Suggested Citation}

Kelly, L. (2021). Humanitarian evidence and discourse summary No.22. K4D Helpdesk Report. Brighton, UK: Institute of Development Studies, DOI: 10.19088/K4D.2022.005 